\title{
Prediction of the Success Level of Entre- preneurial Ventures by means of Biographical and Business Variables in a Third World Setting
}

\section{A B Boshoff, S W Theron and J L Schutte}

\section{University of Pretoria}

\section{ABSTRACT}

A study to determine the degree to which biographical and business variables can predict entrepreneurial success is described. Archival data obtained from the records of a venture capital organization were used. Data were obtained for two cohorts, each of which represented individuals to whom financial assistance was provided in a given financial year. Criterion data consisted of the entrepreneurs' accounts three or four years later. The total sample consisted of 569 small business owners in 435 business firms. Data were captured on 14 biographical and 16 business variables. A statistical analysis strategy to limit capitalization on chance was implemented. The results indicated that the number of loans granted, nationality of entrepreneurs, security cover, education level, economic sector, number of dependants, language preference, and race appeared as predictors of success.

JEL M 130

\section{INTRODUCTION}

"Entrepreneurship as we all know is in vogue" (Kaplan, as quoted by Schutte, Bennett, and Boshoff, 1993: 2) sums up the current enchantment with entrepreneurship in the Western World. This strong interest in entrepreneurship is probably partly due to findings that new business enterprises are the primary source of new employment opportunities (Schutte, Bennett, and Boshoff, 1993: 2). With unemployment at high levels the interest in entrepreneurship as a way of creating jobs is understandable. McClelland (1987) and Harper (1991) argue that entrepreneurship has a critical role to play in economic development and that this role is even more important in the poorer nations of the world. Barry (1985: 139) sees economic activity as consisting of continually exploiting price differences that exist in a necessarily imperfect world. It is a course that 
constitutes profit, a phenomenon which is absent from an equilibrium world. If there were no possibility of profit there would be nothing to drive the system towards equilibrium. In Hayek's instructive phrase the market is a "discovery procedure" rather than an "allocative device" by which means are somehow mechanistically directed towards the production of given ends. This approach appreciates the role of individuals and what Littlechild (1986) describes as "entrepreneurship" in a generic sense as the mainspring of economic change and progress (Ball, 1982: 17).

Under these circumstances Carland, Hoy, and Carland (1988) strongly argue that understanding of entrepreneurship will be enhanced by studying the characteristics of entrepreneurs, and such studies, therefore seem called for in South Africa too. The Quarterly Bulletin of the Reserve Bank (as quoted by Lunsche, 1997) noted with concern that "A somewhat disquieting aspect of long-term employment trends in the South African economy is that the number of job opportunities created during an economic recovery is getting smaller with each successive recovery". Figures confirm this trend, and, seen against the background of about 300,000 new school leavers entering the job market every year, this trend is nothing short of catastrophic. It makes the targets espoused in the Budget - gradually raising the job creating capacity of the economy to 400,00 by the year 2000 - appear like wishful thinking.

Most economists find the answer in an inflexible labour regime. The options are to invest in technology and make existing staff work harder. The Reserve Bank confirms that 1996 witnessed strong productivity growth and real output per worker which had increased by $3,3 \%$ in 1995 , rose further by some $3 \%$ in the first three quarters of the following year. A solution to the South African job crisis, may yet be found in entrepreneurial activity (Lunsche, 1997: 22).

Erez (1993) argues that, if societies indeed organize themselves around the principle of free markets and free enterprise as is now the case in the ex-Soviet bloc, China, and other states, and if entrepreneurship and innovation are the driving forces behind free enterprise, as many believe, then growing importance will be attached to the development and growth of entrepreneurship in the developing countries too. And, during the 1980 s, a period when many large American and European firms downsized, net job creation came almost entirely from entrepreneurial businesses.

It is therefore essential to understand the nature of entrepreneurial orientation and activity in a developing South Africa and its striving for international competitiveness. Studies on the personality characteristics of successful entrepreneurs are therefore warranted, especially if South Africa with its rich 
natural and human resources is to forge ahead to a more prosperous future now that it has rid itself of the restrictive Apartheid policies. South Africa appears to be in short supply of bold and innovative entrepreneurs, perhaps because the political environment is not yet completely congenial to the genesis of entrepreneurial skills (Financial Mail, 1996). Studies on these personality characteristics have not yet yielded a clear picture (Boshoff, Bennett, and Owusu, 1992). Gartner (1988: 21) summarized the situation as follows: "A startling number of traits and characteristics have been attributed to the entrepreneur and a psychological profile of the entrepreneur assembled from these studies would portray someone larger than life, full of contradictions, and conversely someone so full of traits that he/she would have to be a sort of generic Everyman".

Studying business variables as predictors of entrepreneurial success seems to be in line with Gartner's (1988) view that the entrepreneurial process should be studied in more depth. Trying to predict business success seems to be a relevant research objective in the light of the high failure rate of entrepreneurial businesses (Timmons, 1990), especially as venture capital is an active ingredient in many entrepreneurial endeavours (Sahlman, 1994). Birley and Westhead (1994) link up with this argument, reflecting the increased recognition of the importance of both locational considerations in the functioning of the economy and of spational variations in both business formation and small firm survival and growth. Johannesson (1990) argues that the personal network of the entrepreneur is "the strategically most important resource" of the firm. Ostgaard and Birley (1994: 282) are adamant that the value of the network is only realized through the owner-manager's positive use of resources contained within, which implies an interchange with members of the network through some form of networking activity. This is consistent with social network theory relying on two basic premises, viz. the entrepreneurial process involves gathering scarce resources from the environment and resources are usually obtained through contact with the entrepreneur's social network (Ostgaard and Birley, 1994). Dubini and Aldrich (1991: 311) argue that "effective entrepreneurs are able to view effective networking as a crucial aspect of ensuring success of their company". According to them the use of personal networks is a concept sufficiently general to include all business dimensions considered relevant for success, e.g. understanding the business, market orientation, stress on quality, and attention to customers.

Variables of strategic significance which may be used to compare a firm's competitive advantages within and across industries are product / service innovation, marketing, differentiation, focus / scope, and conservative cost control (Ostgaard and Birley, 1994: 284). Hofer and Sandberg (1987) identify 
five business variables of particular strategic importance to the success of new ventures, viz product differentiation; quality, service, and price; market and/or segment domination; innovation; and methods of growth.

In the present study an attempt is made to determine whether and to which degree demographic and business variables could be used as predictors of entrepreneurial success.

\section{METHOD}

Our research approach may be described as archival research, as the data were obtained from the archives of a venture capitalist operating with funding from both government and private sector sources, active in the Northern province of South Africa. The study may therefore be seen as being done by means of "available materials" (Kerlinger, 1986: 468).

The venture capitalist concerned had six different financing schemes in operation. Data from only three of these schemes could be incorporated into the present study. Data from the three other schemes had to be omitted due to the absence of information on biographical characteristics of the individuals to whom loans had been granted.

The loans included in the study were granted between April 1, 1985 and March $31,1987$.

\section{Subjects}

The sample consisted of 569 entrepreneurs active within 435 business enterprises. Of the 569 persons 433 were male and 136 female. More than two thirds, i.e. 392, preferred to communicate in Afrikaans, while 177 preferred English. The majority of the respondents were South African citizens $\mathrm{N}=$ 489). Their average age was 39,5 years with a standard deviation of 9,9 years and a range of 18 - 69 years. 463 respondents were white and 106 black.

\section{Statistical procedure}

The variables included in the study can be seen as typical biographical variables, as well as related to financial and other characteristics of the business venture for which loans had been granted. A list of the variables extracted from the archives is shown in Table 1. 
Table 1: Variables Extracted from the Files of the Venture Capitalist and Scale Categories

\begin{tabular}{|l|l|}
\hline Biographical variables & Categories \\
\hline Race & Black / White \\
\hline Language preference & Afrikaans / English \\
\hline Residential area & City / Town / Rural \\
\hline Education & Years \\
\hline Number of dependants & Number \\
\hline Sex & Male / Female \\
\hline Nationality & South African / Not South African \\
\hline Residential status & Citizen / Not citizen of South Africa \\
\hline Age & Years \\
\hline Employment history & $\begin{array}{l}\text { Related to present venture / Not related to venture / } \\
\text { Organization already exists }\end{array}$ \\
\hline $\begin{array}{l}\text { Apprenticeship / } \\
\text { Clerkship }\end{array}$ & Completed / Not completed / None \\
\hline Marital status & Single / Married / Divorced / Widow / Widower \\
\hline Criminal record & Yes / No \\
\hline Sequestration record & Yes / No \\
\hline Economic sector & $\begin{array}{l}\text { Manufacturing / Retail / Wholesale / Services / } \\
\text { Construction / Foods }\end{array}$ \\
\hline $\begin{array}{l}\text { Purpose of obtaining } \\
\text { finance of }\end{array}$ & $\begin{array}{l}\text { Take-over / New business / Expand existing } \\
\text { business / Unknown }\end{array}$ \\
\hline Number of loans & Number \\
\hline Total amount borrowed & Numerical sum \\
\hline $\begin{array}{l}\text { Percentage own } \\
\text { contribution }\end{array}$ & Ratio of own capital: Total capital of venture \\
\hline Security cover ratio & Ratio of amount of security: Amount borrowed \\
\hline Interest paid on loan & Rate of interest charged by venture capitalist \\
\hline $\begin{array}{l}\text { Legal form of venture } \\
\text { venture }\end{array}$ & $\begin{array}{l}\text { Sole proprietor / Partnership / Close corporation / } \\
\text { Company }\end{array}$ \\
\hline $\begin{array}{l}\text { Entrepreneur's stake in } \\
\text { the venture } \\
\text { venture }\end{array}$ & Percentage of ownership \\
\hline Employment (existing) & Number of employees \\
\hline Employment (additional) & Increase in number of employees since starting \\
\hline Risk classification & Low / Medium / High / Very high \\
\hline tatus of entrepreneur in & Sole proprietor / Partner / Member / Shareholder \\
\hline
\end{tabular}




\begin{tabular}{l}
\hline Table 1 (continued) \\
\begin{tabular}{|l|l|}
\hline Biographical variables & Categories \\
\hline Account status & $\begin{array}{l}\text { Bad debt / Legal control / Current account / Paid-up } \\
\text { loan }\end{array}$ \\
\hline Account number & As indicated by venture capitalist \\
\hline
\end{tabular}
\end{tabular}

The status of the accounts of the entrepreneurs in the venture capitalist's financial records approximately three and four years after the loans had been granted, served as the criterion of success of the subjects' businesses.

The venture capitalist classifies its' clients accounts into four levels:

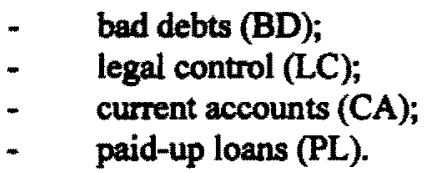

For the purpose of this study the first two (bad debts and legal control) are considered to indicate levels of failure while levels three and four (current accounts and paid-up loans) are seen to depict levels of business success.

One-way Analyses of Variance with Bonferonni's Ranges-test specified where necessary and Chi-square analyses (in the case of nominal variables) were carried out on all the biographical and business variables included in the study with account status (as described) the dependent variable. The analysis was repeated with success/failure as the dependent variable.

These analyses were followed by Stepwise Discriminant Analyses using STEPDISC of SAS (1985). Only variables on which, according to the Analyses of Variance and Chi-square Analyses, successful and unsuccessful entrepreneurs differed were included in the Stepwise Discriminant Analyses. For the purposes of these analyses the variables measured on essentially nominal scales were treated as ordinal in character. More information on how this was done can be found in Schutte (1992). Justification for including variables measured on scales which were not at the interval or ratio levels in Discriminant Analyses is found in Kerlinger (1986: 402).

Also, using the DISCRIM procedure of SAS (1985), Discriminant Analyses were performed to predict success/failure and account status, using only the predictor variables that had not been rejected by the analyses described up to now. 


\section{RESULTS}

The aim of the data analysis was to build predictive models (in terms of the two criteria employed in the study) by means of biographical and business variables. This process was carried out in two phases. The first phase consisted of Analysis of Variance and Chi-square calculations. The second phase of the data analysis consisted of a Stepwise Discriminant Analysis to determine which of the variables identified as potential predictors in the first phase of the analysis could be retained as predictors in the two models i.e. discriminating subjects into (1) account status and (2) success or failure of the subjects' business.

The results of the One-way Analysis of Variance and the Chi-square analysis with account status and success / failure as dependent variables are presented in Table 2.

Table 2: Results of the One-Way Analyses of Variance and Chi-Square Analysis for Account Status and Success or Failure

\begin{tabular}{|c|c|c|c|}
\hline \multirow{2}{*}{$\begin{array}{l}\text { PREDICTOR } \\
\text { variable }\end{array}$} & \multicolumn{3}{|c|}{ Account status } \\
\hline & & & \\
\hline Nominal variables & df & $\mathrm{Chi}^{2}$ & $\mathbf{p}$ \\
\hline Race & 3 & 9,317 & 0,002 \\
\hline Language preference & 3 & 16,56 & 0,001 \\
\hline Sector in economy & 15 & 37,25 & 0,001 \\
\hline Residential area & 6 & 14,75 & 0,022 \\
\hline Nationality & 3 & 13,69 & 0,003 \\
\hline Ordinal / Interval variables & & $\mathbf{F}$ & $\mathbf{p}$ \\
\hline Number of loans & $1 ; 567$ & 7,65 & 0,0001 \\
\hline Amount & $1 ; 567$ & 4,03 & 0,0075 \\
\hline Security cover & $1 ; 567$ & 3,39 & 0,0179 \\
\hline Own contribution & $1 ; 567$ & 4,13 & 0,0066 \\
\hline Education & $1 ; 567$ & 4,12 & 0,0067 \\
\hline Number of dependants & $1 ; 567$ & 4,31 & 0,0051 \\
\hline \multicolumn{4}{|l|}{ Snccess / Failure } \\
\hline Nominal variables & df & $\mathrm{Chi}^{2}$ & $\mathbf{p}$ \\
\hline Race & 1 & 10,774 & 0,013 \\
\hline Sector in economy & 5 & 15,37 & 0,009 \\
\hline Nationality & 1 & 8,690 & 0,003 \\
\hline Ordinal / Interval variables & & $F$ & $\mathbf{p}$ \\
\hline Education & $1 ; 567$ & 11,07 & 0,0009 \\
\hline Interest rate & $1 ; 567$ & 4,30 & 0,0386 \\
\hline Risk classification & $1 ; 567$ & ns & ns \\
\hline
\end{tabular}


According to Table 2 nominal variables having a significant effect on account status are race, language preference, sector in economy, residential area, and nationality. Ordinal / Interval variables significantly influencing account status are number of loans, amount, security cover, own contribution, education, and number of dependants. As regards success / failure, nominal variables having a significant effect are race, sector in the economy, and nationality while education, interest rate, and risk classification are the ordinal / interval variables significantly effecting success / failure.

As regards the second phase of data analysis, the results of the Stepwise Discriminant Analysis are presented in Table 3.

As is evident from Table 3, eight predictor variables, viz. number of loans, language preference, economic sector, own contribution, number of dependants, nationality, security cover, and education level form a relatively weak but statistically significant prediction module to predict the account status of the subjects. Four of these variables are classified as biographical variables and four as business variables (Schutte, Bennett, and Boshoff, 1993: 8). The best discriminating predictor variable contributing to the prediction equation is the number of loans with a Wilks' Lambda of 0,96 at a significance level of $p>F=$ 0,0001 . However, the discriminatory power of this predictor variable is rather weak as it only explains a relatively small amount of the variance $\left(R^{2}=0,038\right)$. Therefore it may be concluded that the relatively weak Wilks' Lambda and canonical correlation $(0,82$ and 0,0661 with a $p<0,0001$ respectively) point to a significant but weak model to be developed predicting account status of the subjects.

Table 3: Results of Stepwise Discriminant Analysis for Classifying Subjects into Account Status Groupings

\begin{tabular}{|l|c|c|c|c|c|}
\hline $\begin{array}{l}\text { Predictor } \\
\text { variable } \\
\text { entered }\end{array}$ & $\begin{array}{l}\text { Partial } \\
\mathbf{R}^{2}\end{array}$ & $\mathbf{F}$ & $\mathbf{p}>\mathbf{F}$ & $\begin{array}{l}\text { Wilks' } \\
\text { Lambda* }\end{array}$ & $\begin{array}{l}\text { Average } \\
\text { canonical } \\
\text { correlation }\end{array}$ \\
\hline $\begin{array}{l}\text { Number of } \\
\text { loans }\end{array}$ &, 0379 & 7,41 &, 0001 &, 96 &, 0126 \\
\hline $\begin{array}{l}\text { Language } \\
\text { preference }\end{array}$ &, 0295 & 5,70 &, 0008 &, 93 &, 0225 \\
\hline $\begin{array}{l}\text { Economic } \\
\text { sector }\end{array}$ &, 0256 & 4,918 &, 0022 &, 91 &, 0307 \\
\hline $\begin{array}{l}\text { Own } \\
\text { Contribution }\end{array}$ &, 0257 & 4,937 &, 0022 &, 89 &, 0389 \\
\hline
\end{tabular}


Table 3 (continued)

\begin{tabular}{|l|c|c|c|c|c|}
\hline $\begin{array}{l}\text { Number of } \\
\text { dependent }\end{array}$ &, 0203 & 3,873 &, 0093 &, 87 &, 0454 \\
\hline Nationality &, 0191 & 3,635 &, 0128 &, 85 &, 0516 \\
\hline Security cover &, 0179 & 3,396 &, 0177 &, 84 &, 0573 \\
\hline Education level &, 0144 & 2,703 &, 0449 &, 82 &, 0662 \\
\hline${ }^{*} p<, 0001$
\end{tabular}

The Stepwise Discriminant Analysis was repeated with the success / failure rate of the group the dependent variable in an attempt to establish whether a prediction model could be built for this criterion. Businesses of subjects were regarded as successful when their account status was given as either "paid up" or "current". Failure was seen as all cases where the account status was either "under legal control" or "insolvent". The results of stepwise discriminant analysis are presented in Table 4.

Table 4: Results of Stepwise Discriminant Analysis Predicting Success / Failure

\begin{tabular}{|l|l|l|c|c|c|}
\hline $\begin{array}{l}\text { Predictor } \\
\text { variable } \\
\text { entered }\end{array}$ & $\begin{array}{l}\text { Partial } \\
\mathbf{R}^{2}\end{array}$ & $\mathbf{F}$ & $\mathbf{p}>\mathbf{F}$ & $\begin{array}{l}\text { Wilks' } \\
\text { Lambda* }\end{array}$ & $\begin{array}{l}\text { Average } \\
\text { canonical } \\
\text { correlation* }\end{array}$ \\
\hline $\begin{array}{l}\text { Educational } \\
\text { level }\end{array}$ &, 0190 & 11,01 &, 0010 &, 98 &, 0190 \\
\hline Nationality &, 0136 & 7,80 &, 0054 &, 97 &, 0324 \\
\hline Race &, 0077 & 4,36 &, 0372 &, 96 &, 0398 \\
\hline "p<,001
\end{tabular}

As is evident from Table 4, and as could be expected in the case of a dichotomous criterion, the prediction model was less strong with only three predictor variables entering the model and the values of Wilk's Lambda and the canonical correlation indicating weak and thus less strong predictions.

The results of the Stepwise Discriminant Analyses described up to this point are summarised in Table 5. 
Table 5: Summary of Predictor Variables with Significant Discriminating Power for the Two Criteria of Success

\begin{tabular}{|l|c|l|}
\hline \multicolumn{3}{|l|}{ CRITERIA OF SUCCESS } \\
\hline Variables & Account status & Success / Failure \\
\hline & Total sample & Total sample \\
\hline $\begin{array}{l}\text { Number of } \\
\text { loans }\end{array}$ & $*$ & \\
\hline Nationality & $*$ & \\
\hline Education level & $*$ & \\
\hline $\begin{array}{l}\text { Economic } \\
\text { sector }\end{array}$ & $*$ & \\
\hline $\begin{array}{l}\text { Language } \\
\text { preference }\end{array}$ & $*$ & \\
\hline Security cover & $*$ & \\
\hline $\begin{array}{l}\text { Number of } \\
\text { dependants }\end{array}$ & $*$ & \\
\hline Race & & \\
\hline $\begin{array}{l}\text { Amount } \\
\text { borrowed }\end{array}$ & & \\
\hline $\begin{array}{l}\text { Own } \\
\text { contribution }\end{array}$ & & \\
\hline Interest rate & & \\
\hline Significant prediction & \\
\hline
\end{tabular}

It is evident from Table 5 that variables applicable on a personal level, viz. nationality, educational level, and race influence the success / failure criterion. Business variables are related to account status.

To determine the strength of the prediction model which could be obtained by means of the predictor variables identified in the previous analytical phases Discrimant Analyses were carried out. The percentages of subjects placed in the correct groups in terms of the two criteria, viz account status and success level by the Discriminant Analyses are shown in Table 6. 
Table 6: Percentages of Subjects in Each of the Four Levels of Account Status and the Two Levels of Success Status Correctly Categorized by Discriminant Analysis for Each Level

\begin{tabular}{|l|l|}
\hline GROUPS & $\begin{array}{l}\text { TOTAL } \\
\mathbf{N}=\mathbf{5 6 9}\end{array}$ \\
\hline Account status & \multicolumn{2}{|l|}{} \\
\hline Bad debts & $34,57 \%$ \\
\hline Legal control & $54,55 \%$ \\
\hline Current account & $38,38 \%$ \\
\hline Paid-up loans & $52,17 \%$ \\
\hline Success level & \\
\hline Unsuccessful & $25,24 \%$ \\
\hline Successful & $86,50 \%$ \\
\hline
\end{tabular}

To facilitate this comparison a model which is commonly used in decision making in personnel selection (Beach, 1985) was used. This model is presented in Figure 1.

Figure 1: Model of The Influence of Relationship Between Predictor and Criterion Scores on Selection Decisions

\begin{tabular}{|c|c|}
\hline $\begin{array}{c}\text { False } \\
\text { Rejections }\end{array}$ & $\begin{array}{c}\text { Valid } \\
\text { Acceptance }\end{array}$ \\
$\begin{array}{c}\text { Valid } \\
\text { Rejections }\end{array}$ & $\begin{array}{c}\text { False } \\
\text { Acceptances }\end{array}$ \\
\hline
\end{tabular}

(Source: Beach, 1985)

This model enables an organization to compare results obtained by a selection procedure with the predicted results (results which would have been obtained if the predictors identified as significant were used in the selection procedure). The number and percentages of Valid Acceptances, False Acceptances, Valid Rejections, and False Rejections could be determined both in reality, i.e. as manifested in the venture capitalist's records and for the predictions, i.e. the categorization of subjects obtained by means of discriminant analysis (Schutte, 1992: 99). Particulars of this comparison are presented in Table 7. 
Table 7: Predicted Success Levels (Percentages) Using Significant Biographical / Business Variables on Small Business Owners" Success Level and Account Status

\begin{tabular}{|c|c|c|c|c|}
\hline & Success L & & Account S & tus \\
\hline Groups & Unsue \% & Suce \% & Unsuc \% & Suce $\%$ \\
\hline Successful & $\begin{array}{l}\text { FR } \\
8,6\end{array}$ & $\begin{array}{r}\mathrm{VA} \\
55,2\end{array}$ & $\begin{array}{r}\text { FR } \\
25,1\end{array}$ & $\begin{array}{r}\text { VA } \\
38,7\end{array}$ \\
\hline Unsuccessful & $\begin{array}{l}9,1 \\
\text { VR } \\
\end{array}$ & $\begin{array}{r}27,1 \\
\text { FA } \\
\end{array}$ & $\begin{array}{r}19,7 \\
\text { VR }\end{array}$ & $\begin{array}{r}16,5 \\
\text { FA }\end{array}$ \\
\hline $\begin{array}{l}\text { FR }=\text { False rejection } \\
\text { VR }=\text { Valid rejection } \\
\text { VA }=\text { Valid acceptance }\end{array}$ & \multicolumn{4}{|c|}{$\begin{array}{l}\text { FA = False acceptance } \\
\text { Unsuc = Unsuccessful } \\
\text { Succ = Successful }\end{array}$} \\
\hline
\end{tabular}

The contents of this table seem to indicate that the prediction (selection) models created by the analyses would improve the selection of small business owners to be granted loans, in the sense that fewer false acceptances (loans granted but the business failed) would be found. The prediction model, therefore, seems capable of successful prediction and the elimination of failures.

\section{DISCUSSION}

The results presented in the previous section seem to indicate that the use of biographical and business variables hold the promise of improving the selection process used to decide which small business owners should be funded by a venture capitalist. Variables which appeared as potent and promising predictors of success or failure appear to be different with remarkably little overlap. Number of loans granted, nationality of entrepreneurs, security cover, education level, economic sector in which business operated, number of dependants, language preference, and race appeared as potent and promising predictors of the success or failure of small business owners.

The predictors which did appear seem to be quite different from what has been found in previous studies. Most of the "traditional" biographical variables like age, gender, and marital status failed to survive the elimination process used in this study. In this sense the present study is seen to represent a contribution to the understanding of the entrepreneurial personality. Race is usually seen as a major characteristic in the complex South African society. This variable did, however, not feature prominently as a predictor of success in the present study. 
This is likely to have important socio-economic and political implications for the development of South African society with regard to its great problems, e.g. unemployment among all sectors of the population.

The study has some clear shortcomings. The criteria of success used are in many ways naive and simplistic due to lack of information on, for instance, financial ratios (Schutte, Bennett, and Boshoff, 1993). The study was essentially a concurrent validity study where an attempt was made to predict success as a small business owner on a selected group without taking into account that a number of applications had been rejected by the venture capitalist. Data from only three loan programmes, albeit the largest three, operated by the venture capitalist was used, making the sample less representative of small business owners in the country. Problems regarding the short time period over which the study was done have already been mentioned.

However, it is hoped that the implication of this study may enable venture capitalists, in a modest way, to identify entrepreneurial potential at an early stage and ensure that the right person is financially supported, thus minimising the losses caused by the financing of business ventures that eventually fail. It might therefore contribute something positive to the much needed economic growth in South Africa.

\section{REFERENCES}

1. BALL, J. (1992). The creation of wealth. In: Ball, J. (Ed.), The Economics of Wealth Creation, Harts, UK: Edward Elgar, 4 - 30.

2. BARRY, N. (1985). In defence of the Invisible Hand. Cato Journal, S(1), $133-148$.

3. BEACH, D.S. (1985). Personnel - The Management of People at Work. Fifth Edition. New York: MacMillan Publishing Company.

4. BIRLEY, S. and WESTHEAD, P. (1994). A Taxonomy of Business Start-up Reasons and their Impact on Firm Growth and Size. Journal of Business Venturing, 9, $7-31$.

5. BOSHOFF, A.B., BENNETT, H.F. and OWUSU, A.A. (1992). Entrepreneurship Research: Where are we and where should we be going? Development Southern Africa, 9(1), 47 - 64.

6. CARLAND, J.W., HOY, F. and CARLAND, J.C. (1988). "Who is an entrepreneur?" Is a question worth asking. American Journal of Small Business, Spring, 33 - 39.

7. DUBINI, P. and ALDRICH, H. (1991). Personnel and Extended Networks are Central to the Entrepreneurial Process. Journal of Business Venturing, 6, $305-313$. 
8. FINANCIAL MAIL. (1996). Entrepreneurship. Freedom Nourishes Innovative Thinking. Financial Mail, 140(12), 26 - 28.

9. EREZ, M. (1993). Facilitating Entrepreneurial Orientation and Behaviour in Developing Countries. Research Proposal, International Research Project. Faculty of Industrial Engineering and Management, Technion City, Haifa, Israel.

10. GARTNER, W.B. (1988). "Who is an entrepreneur?" Is the wrong question. American Journal of Small Business, Spring, 12, 11 - 32.

11. HARPER, M. (1991). Enterprise Development in Poorer Nations. Entreprenewrship Theory and Practice, 15(4), 7 - 11.

12. HOFER, C.W. and SANDBERG, W.R. (1987). Improving New Venture Performance: Some Guidelines for Success. American Joumal of Small Business, 12(4), 41 - 56.

13. JOHANNESSON, B. (1990). Economies of Overview - Guiding the External Growth of Small Firms. International Small Business Journal, $9(1), 32-44$.

14. KERLINGER, F.N. (1986). Foundations of Behavioural Research. Third Edition. New York: Holt, Rinehart and Winston.

15. LITTLECHILD, S.C. (1986). The Fallacy of a Mixed Economy. London: Institute of Economic Affairs.

16. LUNSCHE, S. (1997). Jobless wait in the queue as employed work harder. Sunday times, Business Times, March 23, 1997, 22.

17. MeCLELLAND, D.C. (1987). Characteristics of Successful Entrepreneurs. The Journal of Creative Behaviour, 21(3), 219 - 233.

18. OSTGAARD, T.A. and BIRLEY, S. (1994). Personal Network and Firm Competitive Strategy - A Strategic or Coincidental Match? Journal of Business Venturing, 6, 305-313.

19. SAS INSTITUTE, INC. (1985). SAS Users Guide: Statistics, Version 5 Edition. Carvy, NC: SAS Institute, Inc.

20. SAHLMAN, W.A. (1994). Insights from the Venture Capital Model of Project Governance. Business Economics, 29, 35 - 37.

21. SCHUTTE, J.L. (1992). Prediction of Small Business Owners Success Level by Means of Biographical and Business Variables. University of Natal,Durban: Unpublished M.Com-Thesis.

22. SCHUTTE, J.L., BENNETT, H.F., and BOSHOFF, A.B. (1993). Prediction of the Success Level of Entrepreneurial Ventures by Means of Biographical and Business Variables in a Third World Setting. Paper delivered at International Conference on Entrepreneurship, Vienna, Austria, July 4 - 7, 1993.

23. TIMMONS, J.A. (1990). New Venture Creation (Third Edition). Humewood, Illinois: Irwin. 